Om begreppen produktivitet, rentabilitet och relativ afkastning inom jordbruket Author(s): Knut Wicksell

Source: Ekonomisk Tidskrift, Årg. 5 (1903), pp. 169-174

Published by: Wiley on behalf of The Scandinavian Journal of Economics

Stable URL: http://www.jstor.org/stable/3436820

Accessed: 24-06-2016 13:45 UTC

Your use of the JSTOR archive indicates your acceptance of the Terms \& Conditions of Use, available at

http://about.jstor.org/terms

JSTOR is a not-for-profit service that helps scholars, researchers, and students discover, use, and build upon a wide range of content in a trusted digital archive. We use information technology and tools to increase productivity and facilitate new forms of scholarship. For more information about JSTOR, please contact support@jstor.org.

Wiley, The Scandinavian Journal of Economics are collaborating with JSTOR to digitize, preserve and extend access to Ekonomisk Tidskrift 


\section{Om begreppen produktivitet, rentabilitet och relativ afkastning inom jordbruket.}

Några ord i mitt svar till prof. Fahlbeck (Ekon. Tidskr. dec. 1902) har gifvit d:r Joh. Leffler anledning att $\mathrm{i}$ ett eljest hufvudsakligen mot hr F. riktadt föredrag i Statistisk Förening äfven vända sig mot min, enligt hans uppfattning alltför pessimistiska, åsikt om jordbrukets produktivitet. På grund af ett referat af detta föredrag i Sv. Dagbladet tog jag kort därefter till ordet i samma tidning för att klargöra min ståndpunkt. Då nu emellertid hithörande delar af hans föredrag blifvit tryckta i senaste häfte af Ekon. Tidskr., vill jag litet utförligare bemöta hans anmärkningar, i hopp att därigenom kunna något bidraga till utredningen af en lika viktig som, efter hvad det tyckes, segsliten och till missförstånd lätt föranledande nationalekonomisk fråga.

D:r Leffler förnekar naturligtvis icke in abstracto »lagen om jordens från en viss gräns aftagande produktivitet», en sats, om hvilken han fordom t. o. m. yttrat (Ekon. Samhällslifvet I s. 389) att »dessvärre få satser $\mathrm{i}$ nationalekonomien äro säkrare bestyrkta af erfarenheten än denna»; men han synes mena - ehuru jag verkligen har svårt att förena denna åsikt med hans förträffliga utredning af frågan $i$ äldre skrifter och ej minst på det anförda stället i sistnämnda arbete - att denna lag äfven i de gamla kulturländerna tillsvidare endast har en latent eller potentiell karaktär. Först när den nuvarande jordbrukstekniken uttömt sina resurser, skulle lagen i verkligheten göra sig gällande, eller om den faktiskt redan nu är verksam, så beror detta på att den individuella jordbrukaren saknar »vilja, kunskap, teknisk skicklighet eller ekonomisk för- 
måga» att tillgodogöra sig de förbättringar, som våra dagars jordbruksvetenskap ställer till hans förfogande. Såsom stöd för denna åsikt anför d:r Leffler de bekanta siffrorna rörande medelskörden af spannmål pr hektar i olika länder, hvaraf framgår, att denna i vissa länder (Storbritannien, Nederländerna, Belgien samt Danmark och äfven Norge) är betydligt större, ja ända till dubbelt så stor som i vissa andra, af naturen minst lika gynnade länder (Österrike, Ungarn, Frankrike, Italien).

Ifrăgasättas kan väl emellertid för det första, om man utan vidare har rätt att tillskrifva detta förhållande bristande tekniska insikter i de länder, som ha ett lägre korntal att uppvisa. Faktiskt har ju i flera bland dessa den sädesbärande, och särskildt den för produktionen af brödsäd afsedda, jordarealen en ofantlig utsträckning, hvaremot i flertalet af de länder, som skylta med hög afkastning pr hektar, den mesta jorden användes till frambringande af foderväxter eller såsom betesmark. Detta torde förklara åtskilligt, ty genom den rikligare tillgång på stallgödsel äfvensom på dragare, som häraf blir en följd, kunna ju då de relativt små arealer, som användas för sädesodling, lätteligen bringas upp i högre växtkraft, utan att detta behöfver bevisa en mera framskriden jordbruksteknik.

Härmed må emellertid vara huru som helst - i rent tekniska jordbruksfrågor böjer jag mig alltför gärna för d:r Lefflers auktoritet. Men äfven antaget, att han här hade rätt i förutsättningen, så följer, synes mig, däraf ingalunda den slutsats han vill draga. Så vidt jag nämligen riktigt förstått hans resonnemang, begår $\mathrm{d}$ :r Leffler det förbiseendet att icke strängt skilja mellan jordbrukets relativa afkastning å ena sidan och dess rentabilitet under gifna löneförhållanden å den andra. Detta är dock två alldeles skilda saker. Jordbrukets rentabilitet kan vid tillräckligt låga arbetslöner och låg kapitalränta fortfara att ökas, långt efter det att gränsen för den högsta relativa af kastningen (bruttoprodukten dividerad med antalet arbetare eller med antalet enheter »arbete och kapital») är passerad.

Ett konkret exempel skall bäst visa detta, hvarvid jag dock för enkelhetens skull alldeles bortser från kapitalet såsom produktionsfaktor; resonnemanget blir $\mathrm{i}$ allt väsentligt detsamma, vare sig det medtages eller ej. Vi vilja antaga, att en stor jordägare på sin jord sysselsätter (direkt eller indirekt) 100 arbetare. Årslönen pr arbetare är 500 kronor, bruttoinkomsten har ett värde af $100,000 \mathrm{kr}$., lämnande alltså åt jordägarenföretagaren, sedan arbetslönerna blifvit betalda, en nettobehållning af 50,000 kr. Vid full rationell arbetsanvändning skulle han emellertid, vilja vi vidare antaga, kunna uppdrifva afkastningen pr hektar från 20 till 23 
deciton, ifall han på sin jord anställer 25 nya arbetare. Bruttoproduktens värde har därigenom ökats med $15,000 \mathrm{kr}$., och då de nya arbetslönerna endast uppgå till 12,500 kr., erhåller han alltså för egen del ett tillskott till sin nettovinst af $2,500 \mathrm{kr}$. Det har sålunda nu lyckats honom att "med växande nettobehållning genom stegrad intensitet» uppnå en »betydligt större produktion af närings- och råämnen» än förut, och detta utan att arbetslönerna ha minskats. Det kunde ju alltså tyckas, som om »vid nutida pris å arbetskraft ... den ifrågavarande jordbruksproduktivitetslagen ännu icke börjat märkbart göra sig gällande». Men detta vore ett stort misstag. Jordbruksproduktivitetslagen har nog hela tiden varit gällande, och gränsen för den högsta relativa afkastningen - hvilken, i parentes sagdt, alls icke är beroende af nutida pris på arbetskraft och arbetsmedel - har säkerligen för länge sedan öfverskridits. Medan nämligen förut hvarje anställd arbetare i genomsnitt producerade för $\mathrm{I}, 000 \mathrm{kr}$ :s värde, utgör efter ökningen af arbetareantalet den genomsnittliga produktionen pr arbetare allenast II 5,000: I25 $=920 \mathrm{kr}$. Gå vi nu åter tillbaka och antaga, att jordägaren successivt minskade sin arbetarestock i stället för att öka den, så skulle antagligen afskedandet af de första 25 man komma arbetsprodukten att minskas med ungefär lika mycket, som ökningen förut utgjorde, dock med något mer, låt oss säga $15,500 \mathrm{kr}$; en följande minskning af arbetarestocken med likaledes 25 man skulle komma bruttoproduktens värde att sjunka med t. ex. 16,500 kr. och en tredje dylik med I8,000 kr., eller sammanlagdt 50,000 kr., så att, när antalet arbetare sammankrympt till en fjärdedel af det ursprungliga, bruttoprodukten endast hade minskats till hälften, hvadan hvarje arbetare nu i genomsnitt producerar för 2,000 kr:s värde eller dubbelt mot förut. Gränsen för den högsta möjliga relativa afkastningen ligger förmodligen ännu något längre tillbaka, t. ex. vid I 5 eller Io arbetare, hvaremot en ytterligare minskning skulle komma afkastningen att sjunka äfven relativt. Här ligger alltså enligt de gjorda förutsättningarna den »höjdpunkt, där jordbruksproduktivitetslagen», $\mathrm{i}$ ordets vetenskapliga mening, först »börjar göra sig gällande».

Men, invänder någon kanhända, detta är ju blott ett tänkt exempel. Hvarför icke lika gärna förutsätta, att ökningen eller minskningen af den totala afkastningen sker rent proportionellt med antalet arbetare, så att en ökning af arbetsstyrkan med $25 \%$ också skulle åstadkomma bruttoproduktens ökande med en fjärdedel o. s. v.? $N e j$, detta antagande kan icke göras, det strider ögonskenligen mot verkligheten. Förhölle det sig så, blir det öfverhufvud omöjligt att förklara, hur något pris på jorden, 
någon jordränta $\mathrm{i}$ egentlig mening skulle kunna uppstå. Hvem ville väl betala något pris för att öka sin jordbesittning, om han på en mindre areal kunde åstadkomma alldeles samma afkastning med en gifven mängd arbete och kapital? Ännu enklare ställer sig saken, om man vänder om frågan och tar arbetskraften till utgångspunkt $i$ stället för jorden. Skulle t. ex. någon uppkasta det spörsmålet, huruvida en liten parcellbesittare, som nu nätt och jämt kan lifnära sig på några få tunnland jord, skulle få det bättre ställdt, ifall han finge använda sin egen och familjens arbetskraft på ett dubbelt så stort stycke lika god jord, så skulle väl hvarje erfaren jordbrukare endast ha ett småleende till svar på en så enfaldig fråga. Det vore ju utan vidare själfklart. Men är detta själfklart, så är också lagen för jordbrukets sjunkande produktivitet, såsom en faktiskt, icke blott $\mathrm{i}$ framtiden verksam lag, själfklar, ty detta är ju alldeles samma sak, blott från andra sidan sedt.

Äfven hänvisningen till möjliga tekniska framsteg inom jordbruket betyder i detta sammanhang intet. Dessa hafva i stort sedt blott den verkan, att de så att säga uppflytta hela serien af successivt aftagande produkttillskott på ett högre plan, men förändra därigenom ingenting af själfva lagens allmänna karaktär. På en jordareal, där man för ett århundrade sedan sysselsatte 5 arbetare, användas i dag kanhända Io arbetare, och hvar och en af dessa Io producerar på grund af förbättrade jordbruksmetoder mera än hvar och en af de 5 för hundra ăr sedan; men detta hindrar icke, att den genomsnittliga produkten pr man skulle bli än större, om antalet arbetare $n u$ minskades från Io till 5 o. s. v. ${ }^{1}$

Med ett ord »jordbruksproduktivitetslagen» som kanske enklast kan uttryckas så, att det intensiva jordbruket lämnar mera pr hektar och det extensiva mera pr arbetare, torde få betraktas såsom fullt generell och aktuell, gällande på hvarje jordbruksteknisk ståndpunkt, om också icke alltid på fullkomligt samma sätt. Det intensiva jordbruket är naturligtvis $\mathrm{i}$ ett tätt befolkadt land högeligen värdefullt eller rättare sagdt oumbärligt för att åstadkomma tillräcklig föda åt befolkningen, men i och för sig utgör det en nödfallsutväg, som uteslutande betingas af den relativa bristen på jord. „Hade vi här $i$ landet eller öfverhufvudtaget $i$ Europa» - yttrade jag i den nämnda tidningsuppsatsen — »lika godt om åkerjord, som fallet ännu är i Amerika, så skulle ingen människa, säkerligen icke

1 Ville man urgera d:r Lefflers sats, så skulle ju f. ö. till och med all skillnad mellan bättre och sämre jord upphäfvas, ty hvem kan neka till att, om odlingen inskränktes till den bättre jorden, den skulle lämna större genomsnittlig afkastning pr arbetare? 
en fackman som d:r Leffler ens sätta i fråga att använda det nuvarande intensiva brukningssättet; vi skulle plöja lika grundt och gödsla lika sparsamt, som det faktiskt sker i Argentina eller Förenta staterna; vi skulle därigenom visserligen få en vida mindre skörd än nu pr hektar, såsom fallet också är i Amerika» - i parentes sagdt förvånar det mig, att d:r Leffler icke anfört de så belysande amerikanska skördesiffrorna - »men vi skulle få ett långt rikare utbyte af vårt på jorden nedlagda arbete och kapital, och detta vore ju under sådana omständigheter hufvudsaken ${ }^{1}$. "Naturligtvis», fortsatte jag, "finnes äfven för det extensiva jordbruket en gräns, som icke lämpligen kan öfverskridas: en familj kan t. ex. icke godt sköta mer än ett 50-tal hektar åker och äng - storleken af den amerikanska homesteadfarmen - men denna gräns, och det var om den jag talade, få vi väl anses ha i Europa lämnat långt bakom oss.»

Jag vill tillägga, att målet själffallet icke utan vidare kan vara att genom befolkningens uttunnande bringa upp den relativa afkastningen af jorden till den största möjliga höjd - det kan ju tänkas, att den då t. o. m. blefve öfverflödigt stor - men väl måste man med jordbruksproduktivitetslagen i tankarne ovillkorligen komma till den slutsats, att hvarje ökning af folkmängden i ett gammalt, hufvudsakligen jordbruksidkande land $i$ och för sig är ägnad att sänka det allmänna välståndets nivå och särskildt arbetarnes villkor. Kan denna dess verkan motverkas genom samtidiga tekniska förbättringar inom eller utom jordbruket, så är det ju godt, men det blir då $\mathrm{i}$ alla händelser ett plus, som delvis eller helt och hållet uppväges af ett minus, hvaremot dylika förbättringar vid en stationär folkmängd skulle verka med hela sin kraft såsom ett rent plus.

Då det för mig närmast blott gällt att söka klargöra ett teoretiskt ekonomiskt spörsmål, vill jag här icke följa d:r Leffler in på hans betraktelser öfver vårt lands ekonomiska framtid i det hela. Det faller mig icke in att underskatta den varma fosterlandskärlek, ur hvilken de äro framsprungna, men vilja är gunås ett och kunna ett annat, och en nationalekonom borde, synes mig, mer än andra människor vara på sin vakt mot det så vanliga felet att taga drömmar och förhoppningar för verklighet. Hvad som hos folk i allmänhet härvidlag kan vara en förlåtlig svaghet, blir hos vetenskapsmannen, som skulle upplysa och vägleda det allmänna om-

${ }^{1}$ Jämför mitt referat af Pohles bok i föregående häfte s. II7 ff. - Enligt en uppsats i Schmollers Jahrbuch förlidet år skall en kolonist i S:ta Fé eller Cordoba (Argentina) med tillhjälp af en enda arbetare kunna årligen plöja och beså icke mindre än 128 hektar och skörda därpå c:a I,000 (ett tusen) deciton hvete. 
dömet, ett verkligt fel och kan ha de svåraste praktiska konsekvenser. D:r Leffler tillvitar, om än i reserverade ordalag, prof. Fahlbeck att skatta åt »det gamla merkantilistiska postulatet: en relativt mycket talrik arbetarebefolkning, för att lönerna må kunna hållas låga» (och landet därigenom bli mera konkurrensdugligt på den utländska marknaden). Huruvida denna förebråelse formellt är befogad, har jag ej haft tid att efterforska; dock skulle jag a priori vilja fritaga ej mindre min ärade kollega i Lund än d:r Leffler själf från att medvetet fullfölja ett så ledsamt syfte. Men att den lätthjärtade befolkningspolitik, som, sorgligt att säga, d:r Leffler numera ej mindre än prof. Fahlbeck synes hylla, i hög grad är ägnad att framkalla låga löner, därom känner jag mig dessvärre lifligt öfvertygad.

Knut Wicksell. 